Japan. J. Trop. Med., Vol. 10, 1, p. 8-13, 1969

\title{
ON THE LUNG FLUKES CAUSING HUMAN PARAGONIMIASIS*
}

\author{
ICHIRO MIYAZAKI \\ Department of Parasitology, Faculty of Medicine, \\ Kyushu University, Fukuoka, Japan
}

In this paper the author wishes to summarize the lung flukes, which cause human paragonimiasis or which are suspected to infect humans not only in Asia but also in America and in Africa. In Asia, more than 20 species were reported in literature, of which 17 species are regarded as valid (Table 1). Since the author found Paragonimus ohirai in 1939, 14 species have been recorded in Japan, China and Thailand during past 30 years. Recently four species $-P$. siamensis, $P$. bangkokensis, $P$. harinasutai and $P$. sadoensis - were found by the author and his co-workers chiefly in Thailand. From medical point of view, P. westermani is most important widely occurring in Asia; the author reconfirmed this species from South-east Asia to USSR. Another two species were recently proved to be the human parasite; i. e. P. skrjabini (syn. P. szechuanensis Chung et Ts'ao, 1962) was removed from human body on the mainland of China by Chung et al. (1962), and $P$. heterotremus (syn. P. tuanshanensis Chung et al., 1964) was from a boy in Thailand by Miyazaki and Harinasuta (1966). In addition, another species such as $P$. miyazakii, $P$. sadoensis, $P$. bangkokensis and $P$. harinasutai seem to have possibility of human infection, since their crab hosts are not infrequently eaten uncooked or pickled by inhabitants.

In Japan five species are known, of which only $P$. westermani was removed from human body. The main source of human infection with this fluke is a big crab, Eriocheir japonicus. The metacercaria is mainly parasitic in the gill vessel and in the muscle of the crab. Another source of infection is a small crab, Potamon dehaani, which harbors not only $P$. westermani but also $P$. miyazakii and $P$. sadoensis. Because this crab is sometimes eaten uncooked by people, the latter two species are also suspected to infect humans. P. miyazakii parasitizes several kinds of mammals such as the weasel, the martens, the wild boar and the dog. Besides, the fluke was proved by experiment to be able to mature in the albino rat, the Norway rat, the rabbit and the cat. Its first intermediate host is a very small snail, Bythinella nipponica, which lives in mountain streams. The second intermediate host of the fluke is the above-mentioned crab, Potamon dehaani, which is also distributed in mountainous area. Metacercariae parasitic in this crab are mostly $P$. miyazakii and rarely $P$. westermani at present, but formerly those of the former were long confused with the latter by previous investigators. $P$. sadoensis was most recently found on Sado Island, Niigata Prefecture, and was found to be parasitic in the weasel and the cat. The fluke was experimentally proved to parasitize the dog, the albino rat, the wild mouse, the house rat, the Norway rat, the

\footnotetext{
* Supported in part by the Scientific Research Grant from the Ministry of Education, Japan, and in part. by the U. S. Army Research and Development Group (Far East), Department of the Army under Contract No. DAJB17-67-C-0044.
} 
Table 1. Paragonimus occurring in Asia

\begin{tabular}{|c|c|}
\hline Name & Locality \\
\hline 1. P. compactus (Cobbold, 1859) & India, Ceylon \\
\hline 2. P. westermani (Kerbert, 1878) & $\begin{array}{l}\text { India, Ceylon, Thailand, } \\
\text { Indonesia, Malaysia, } \\
\text { Philippines, China, Taiwan, } \\
\text { Ryukyus, Japan, Korea, USSR }\end{array}$ \\
\hline 3. P. ohirai Miyazaki, 1939 & Japan, China \\
\hline 4. P. iloktsuenensis Chen, 1940 & China, Japan, Taiwan \\
\hline 5. P. skrjabini Chen, 1959 & China \\
\hline 6. P. yunnanensis Ho et al., 1959 & China \\
\hline - 7. P. miyazakii Kamo et al., 1961 & Japan \\
\hline 8. P. macrorchis Chen, 1962 & China, Thailand \\
\hline 9. P. fukienensis Tang et Tang, 1962 & China \\
\hline 10. Euparagonimus cenocopiosus Chen, 1962 & China \\
\hline 11. P. cheni $\mathrm{Hu}, 1963$ & China \\
\hline 12. P. heterotremus Chen et Hsia, 1964 & China, Thailand \\
\hline 13. P. proliferus Hsia et Chen, 1964 & China \\
\hline 14. P. siamensis Miyazaki et Wykoff, 1965 & Thailand \\
\hline 15. P. bangkokensis Miyazaki et Vajrasthira, 1967 & Thailand \\
\hline 16. P. harinasutai Miyazaki et Vajrasthira, 1968 & Thailand \\
\hline 17. P. sadoensis Miyazaki et al., 1968 & Japan \\
\hline
\end{tabular}

Japanese vole, Microtus montebelli and the woods mouse, Apodemus speciosus. The snail host of the fluke is Tricula minima living in mountain streams, and the crab host is Potamon dehaani.

Generally speaking, it is not easy to diagnose the species of Paragonimus by its eggs in sputum or in feces. But, typical eggs of $P$. westermani have the gradually thickened eggshell at non-operculated end, and those of $P$. miyazakii are the smallest of the five species and the eggshell is thinner than other species in Japan.

Over 50 years ago, the life cycle of $P$. westermani was clarified by a Japanese doctor, K. Nakagawa in Taiwan by finding its metacercaria in a crab, Potamon rathbuni for the first time. Since then, many kinds of crustacean hosts had been recorded in different parts of Asia. In recent years, six species of fresh-water crabs were decided as the host of $P$. westermani by the author and his co-workers; i. e. Potamiscus johorensis, P. cognatus (unpublished) and Parathelphusa maculata in Malaysia, Potamon smithianus in Thailand, Parathelphusa rugosa in Ceylon (unpublished), and Potamon miyazakii in Taiwan.

The second human lung fluke, P. skrjabini, was found in China, and its natural host is Paguma larvata and the cat. It was also found in subcutaneous nodules of the patients. The body is slender, the ovary is delicately branched, the cuticular spines are single and the testes are very small as compared with the body-size. The source of infection with this parasite is a stone crab, Potamon denticulatus and $P$. yaanensis.

In Thailand, the author has been carrying on joint works with staffs of the Bangkok School of Tropical Medicine in the endemic area in Nakornnayok situated 
about $90 \mathrm{~km}$ from Bangkok. In the area they recognized four known species $-P$. westermani, $P$. siamensis, $P$. heterotremus and $P$. macrorchis, as well as two new species, $-P$. bangkokensis and $P$. harinasutai. Of these six species, $P$. heterotremus and $P$. macrorchis were originally found in the mainland of China. From medical point of view, $P$. heterotremus is most significant in that endemic area, because the eggs in sputum of patients are different from those of $P$. westermani on the one hand, and two immature worms identified as $P$. heterotremus were demonstrated from the skin of a boy residing in the same area on the other hand. The most important morphological feature of this parasite is the far bigger oral sucker than the ventral one ; i. e. the diameter of the former is twice as long as the latter in mature worms. Cuticular spines are single, the ovary is delicately branched and the testes are also branched and larger than the ovary. As the source of infection a big crab, Potamon smithianus is very important, since this crab frequently harbors the metacercaria of $P$. heterotremus and is eaten uncooked by inhabitants. Another lung flukes such as $P$. bangkokensis and $P$. harinasutai have some possibility of human infection, because their metacercariae are also parasitic in the same crab. Particularly, medical attention must be paid to the egg of $P$. harinasutai, the shell of which is not rarely thickened at non-operculated pole just like that of $P$. westermani. Incidentally, the author was surprized to know that the important crab host, Potamon smithianus was infected with six species of Paragonimus metacercariae in one endemic area of Nakorn-nayok. Of these species the metacercaria of $P$. heterotremus is the smallest and that of $P$. harinasutai is the largest, averaging 0.29 by $0.24 \mathrm{~mm}$ and 0.6 by $0.6 \mathrm{~mm}$, respectively.

In recent years, human paragonimiasis has begun to attract medical attention in some countries of Central and South America such as Mexico, Costa Rica, Panama, Colombia, Ecuador, Peru, etc., although some cases of the disease were already reported in former times. But, the causative agent of the disease has not definitely been decided as yet. In the Western Hemisphere only two species $-P$. rudis (Diesing, 1850) and P. kellicotti Ward, 1908 - had been recorded during past over 100 years, and in this year another two species $-P$. caliensis Little, 1968 and $P$. mexicanus Miyazaki et Ishii, 1968 - were reported in Colombia and in Mexico, respectively. Of the four species $P$. rudis is regarded as a nomen nudum at present, and the remainder three are as valid species. According to Miyazaki and Ishii (1968 a, b), P. mexicanus was found in the opossum, Didelphis marsupialis captured in Colima and is similar to $P$. kellicotti in morphology, but they are most easily differentiated from each other by the size of eggs and the thickness of eggshells. After examining some specimens from Guatemala and Panama, the same authors noted that $P$. mexicanus might be occurring also in these countries. Recently, the author received a specimen from Costa Rica, and he identified it as $P$. mexicanus (unpublished). The eggs deposited in the lung tissue of a Mexican male reported by Martínez Báez and Jiménez Galán (1961) did not agree with those of either $P$. westermani or $P$. kellicotti, but they appeared to be those of $P$. mexicanus. This new lung fluke seems to be important in the medical field of Central America.

$P$. caliensis was also found from opossums in Colombia by Little (1968), and characterized by simple branching of the ovary and testes as well as by irregularity of the eggshell. This fluke seems to occur also in Panama and Mexico, but its 
infectivity to humans is unknown as yet.

Ibáeñz and Miranda (1967) found the lung flukes for the first time in Peru, which were collected from a domestic cat in an area of human infections. At their request the author is carrying on taxonomical studies on their materials, and it is likely that this Peruvian fluke is different from known species of Paragonimus, as stated by the authors. On the other hand, the author investigated the eggs in sputum of a Peruvian patient, and clarified that they showed the same character with uterine eggs of the lung fluke from the cat mentioned above. Anyway, human paragonimiasis in Central and South America is suspected to be caused by two or more different species of Paragonimus. However, P. westermani, one of important human parasites in Asia, is most probably not distributed in the Western Hemisphere.

In Africa two species are known; i. e. P. africanus Voelker et Vogel, 1965 in Cameroons and $P$. uterobilateralis Voelker et Vogel, 1965 in Cameroons and Liberia. The former is suspected to infect humans, since its crab hosts, Sudanautes africanus and $S$. pelii, are frequently eaten by inhabitants and the eggs from patients and from experimental animals are similar to each other. Adults of P. africanus are provided with a delicately branched ovary and remarkably large, branched testes just like $P$. macrorchis in Asia, but they are easily distinguished by the fact that $P$. africanus has far bigger oral sucker than ventral one.

In conclusion, the causative agent of human paragonimiasis is not a single species, as thought formerly, but it amounts to several species, which are different not only in morphology but also in ecology and biology.

\section{ACKNOWLEDGEMENT}

The author wishes to express his sincere appreciation to the colleagues in Japan and to the co-workers outside Japan for their kind help to his research, especially to Dr. JuiKuang Chiu of the National Taiwan University in Taipei, Taiwan, to Dr. Dale E. Wykoff of the Makerere University College in Kampala, Uganda, to Drs. Chamlong Harinasuta, Tranakchit Harinasuta and Suvajra Vajrasthira of the University of Medical Sciences in Bangkok, Thailand, to Drs. Ungku Omar-Ahmad and Eh-Hoa Kwo and Mr. Boo Liat Lim of the Institute for Medical Research in Kuala Lumpur, Malaysia, and to Dr. A. S. Dissanaike of the University of Colombo in Ceylon. Thanks are also due to Dr. A. V. Maslov of the Medical. Institute in Khabarovsk, USSR, Dr. Hsin-Tào Chen of the Chung Shan Medical College in Canton, China, Dr. Kr. Suresh Singh of the Indian Veterinary Research Institute in Izatnagar, India, Dr. H. Vogel of the Tropeninstitut in Hamburg, West Germany, Dr. Luis Mazzotti in Mexice, Dr. Maurice D. Little of the Tulane University in New Orleans, USA, Dr. Rodrigo Zeledón of the International Center for Medical Research and Training in San Jose, Costa Rica, Dr. Vernon E. Thatcher of the Gorgas Memorial Laboratory in Panama, and Dr. Nicanor Ibáñez Herrera of the National University of Trujillo in Peru, who supplied the author with valuable specimens and communications, and to Dr. Sadayoshi Miyake of the Kyushu University in Fukuoka, Japan and Dr. C. H. Fernando of the University of Waterloo in Canada, who identified the crab hosts of lung flukes.

\section{LITERATURES Cited}

1) Chen, H. T. (1960): Taxonomic consideration of Paragonimus, including morphological notes on P. skriabini Chen. (Chin. text with Eng. abstr.) Acta Zool. Sinica, 12, 27-36.

2) Chen, H. T. (1962): The etiologic agent of human paragonimiasis in China. Chin. Med. J., 81, 345-353. 
3) Chen, H. T. (1964): The Chinese species of paragonimid trematodes, their phylogenetic relationship and faunal distribution. (Chin. text with Eng. abstr.) Acta Parasit. Sinica, 1, 53-66.

4) Chen, H. T. and Hsia, T. K. (1964): A preliminary report on new species of Paragonimus. 1. P. heterotremus sp. nov. (Chin. text with Eng. abstr.) Zhongshan Daxue Xuebao, 2, 236-238.

5) Chiu, J. K. (1962): Intermediate hosts of Paragonimus westermani at Shenkeng district of Taipei County, Taiwan. J. Parasit., 48, 423-426.

6) Chung, H. L. and Ts'ao, W. C. (1962): Paragonimus westermani (Szechuan variety) and a new species of lung fluke, P. szechuanensis. Part I. Studies on morphology and life history of $P$. szechuanensis. Chin. Med. J., 81, 354-378.

7) Chung, H. L. et al. (1962): Ibid. Part II. Studies on clinical aspects of paragonimiasis szechuanensis - A new clinical entity. Ibid., 81, 419-434.

8) Chung, H. L. et al. (1964): The discovery in Yunnan Province of 2 new species of lung flukes-Paragonimus tuanshanensis sp. nov. and P. menglaensis sp. nov. Part I. Studies on morphology and life history with discussion on possible pathogenicity to man. Ibid., 83, 641-659.

9) Hashiguchi, Y. and Miyazaki, I. (1968): The experimental infection of a snail, Bythinella nipponica akiyoshiensis with larval lung fluke, Paragonimus miyazakii Kamo et al., 1961. (Jap. text with Eng. abstr.) Jap. J. Parasit., 17, 10-18.

10) Ibáñez, N. and Miranda, H. (1967): Paragonimiasis - Hallazgo de formas adultas del genero Paragonimus Braun, 1899 en gato (Felis domesticus Linneo, 1758) procedente de zona endemica, en Cajamarca, Peru. Arch. Peruanos Pat. Clin., 21, 223-236.

11) Kamo, H., Nishida, H., Hatsushika, R. and Tomimura, T. (1961): On the occurrence of a new lung fluke, Paragonimus miyazakii n. sp. in Japan. Yonago Acta Med., 5, 43-52.

12) Kwo, E. H. and Miyazaki, I. (1968): Paragonimus westermani (Kerbert, 1878) from tigers in North Sumatra, Indonesia. J. Parasit., 54, 630.

13) Lee, H. F. and Miyazaki, I. (1965): Paragonimus westermani infection in wild mammals and crustacean host in Malaysia. Amer. J. Trop. Med. Hyg., 14, 581-585.

14) Little, M. D. (1968): Paragonimus caliensis sp. n. and paragonimiasis in Colombia. J. Parasit., 54, 738-746.

15) Martínez Báez, M. and Jiménez Galán, A. (1961): Un caso de trematodiasis pulmonar registrado en Mexico. Rev. Inst. Salubr. Enferm. trop. (Mex.), 21, 101-114.

16) Mazzotti, L. and Miyazaki, I. (1965): The first record of adult lung flukes Paragonimus in Mexico. Jap. J. Parasit., 14, 34-36.

17) Miyake, S. and Chiu, J. K. (1965): A new potamonid crab, Potamon (Geothelphusa) miyazakii sp. nov., as an intermediate host of the lung fluke from Formosa. J. Fac. Agr. Kyushu Univ., 13, 595-600.

18) Miyazaki, I. and Harinasuta, T. (1966): The first case of human paragonimiasis caused by Paragonimus heterotremus Chen et Hsia, 1964. Ann. Trop. Med. Parasit., 60, 509514.

19) Miyazaki, I. and Ishii, Y. (1968 a): Comparative study of the Mexican lung flukes with Paragonimus kellicotti Ward, 1908. J. Parasit., 54, 845-846.

20) Miyazaki, I. and Ishii, Y. (1968 b): Studies on the Mexican lung flukes, with special reference to a description of Paragonimus mexicanus sp. nov. Jap. J. Parasit., 17, 445453.

21) Miyazaki, I. and Vajrasthira, S. (1967 a): Occurrence of the lung fluke, Paragonimus heterotremus Chen et Hsia, 1964 in Thailand. J. Parasit., 53, 207.

22) Miyazaki, I. and Vajrasthira, S. (1967 b): On a new lung fluke, Paragonimus bangkokensis sp. nov. in Thailand. Jap. J. Med. Sci. Biol., 20, 243-249. 
23) Miyazaki, I. and Vajrasthira, S. (1967 c): Occurrence of the lung fluke, Paragonimus macrorchis Chen, 1962 in Thajland. J. Parasit., 53, 894-895.

24) Miyazaki, I. and Vajrasthira, S. (1968): On a new lung fluke found in Thailand, Paragonimus harinasutai sp. nov. Ann. Trop. Med. Parasit., 62, 81-87.

25) Miyazaki, I. and Wykoff, D. E. (1965): On a new lung fluke, Paragonimus siamensis n. sp. found in Thailand. Jap. J. Parasit., 14, 251-257.

26) Miyazaki, I., Kawashima, K. and Tan, M. H. (1968): Parathelphusa maculata de Man, 1879, a new crustacean host record for Paragonimus westermani (Kerbert, 1878) in Malaysia. J. Parasit., 54, 178-179.

27) Miyazaki, I., Kawashima, K., Hamajima, F. and Otsuru, M. (1968): On a new lung fluke, Paragonimus sadoensis sp. nov. found in Japan. Jap. J. Parasit., 17, 149-159.

28) Voelker, J. und Vogel, H. (1965): Zwei neue Paragonimus-Arten aus West-Afrika: $P$. africanus und P. uterobilateralis. Z. Tropenmed. Parasit., 16, 125-148.

29) Vogel, H. und Crewe, W. (1965): Beobachtungen über die Lungenegel-Infektion in Kamerun (Westafrika). Ibid., 16, 109-125. 